\title{
Hyponatraemia in cases of children with pneumonia
}

\author{
Afroditi Sakellaropoulou, Maria Hatzistilianou, Maria Eboriadou, Fanni Athanasiadou-Piperopoulou
}

2nd Department of Paediatrics, Medical School, Aristotle University of Thessaloniki, Greece

Submitted: 14 November 2009

Accepted: 14 February 2010

Arch Med Sci 2010; 6, 4: 578-583

DOI: 10.5114 /aoms.2010.14471

Copyright @ 2010 Termedia \& Banach

\section{Abstract}

Introduction: Hyponatraemia is the most common electrolyte imbalance seen in clinical practice, and a common laboratory finding in children with communityacquired pneumonia (CAP). This study aimed to identify the incidence of hyponatraemia in cases of CAP, to find predictive tools in order to classify the severity and outcome of CAP and to explore possible differences of clinical importance between the two sexes.

Material and methods: The medical files of 54 children ( $66.4 \%$ males), $4.67 \pm 2.88$ years old, were retro-prospectively reviewed.

Results: 35/54 (64.8\%) children with pneumonia had normal values of sodium at admission, 18/54 (33.3\%) had mild hyponatraemia and 1 child (1.9\%) moderate hyponatraemia. Increased heart rhythm and tachypnoea at admission were correlated with lower values of sodium $(z=-2.664, p=0.007$ and $z=-1.705$, $p=0.089$ respectively). No differences were found between the two sexes concerning the characteristics of pneumonia or the range of sodium in serum at admission. A correlation was found between sodium admission values and: a) C-reactive protein $(p=0.000)$, and b) leukocyte count $(p=0.006)$. Sedimentation rate $(p=0.021)$ was also considered as a possible risk factor affecting the value of sodium at admission to hospital. Finally, a negative association was also observed between the degree of hyponatraemia and the duration of hospitalization ( $z=-3.398, p=0.001)$.

Conclusions: Although studies in larger population groups are needed, in our study increased heart rhythm, tachypnoea, leucocyte count, C-reactive protein, and also erythrocyte sedimentation rate could be considered as possible risk factors influencing the degree of hyponatraemia, and thus the outcome of hospitalized children with CAP.

Key words: pneumonia, children, hyponatraemia, risk factors.

\section{Introduction}

Hyponatraemia (HN, serum sodium $<135 \mathrm{mEq} / \mathrm{l}$ ) is the most common electrolyte imbalance seen in clinical practice, and also in critically ill children [1]. It is present in approximately $3 \%$ of hospitalized patients [2]. Mild to moderate $\mathrm{HN}$ and severe hyponatraemia are found in $15-30 \%$ and $1-4 \%$ of hospitalized patients, respectively [3].

Pathophysiologically, HNs are classified into two groups: HN due to nonosmotic hyper-secretion of vasopressin (hypovolaemic, hypervolaemic, euvolaemic) and HN of non-hypervasopressinaemic origin (pseudohyponatraemia, water intoxication, cerebral salt wasting syndrome) [3].

First, in 1920 it was shown that many children with pneumonia retain water [4], which has been found to be associated with an increased blood
Corresponding author:

Afroditi Sakellaropoulou, MD

$2^{\text {nd }}$ Department

of Paediatrics

Medical School

Aristotle University

of Thessaloniki, Greece

E-mail:wx@otenet.gr 
volume and a low plasma chloride value [5]. These findings are explained by the syndrome of inappropriate secretion of anti-diuretic hormone (SIADH), which has been described in children with pneumonia [6], and meningitis [7]. It was found that $\mathrm{HN}$ frequently accompanies pulmonary diseases, infectious and also neoplastic [8].

Hyponatraemia is considered a common laboratory finding in children with communityacquired pneumonia (CAP), which can be defined clinically as the presence of signs and symptoms of pneumonia in a previously healthy child due to an infection which has been acquired outside hospital [9]. Few studies, though, explore the correlation of HN and pneumonia in children [10]. Based on the published studies, the severity of CAP and HN due to CAP are associated with the need of hospitalization, the presence of prolonged and high fever, and elevated serum non-specific inflammatory markers, such as serum C-reactive protein (CRP) and serum procalcitonin [9].

Moreover, lower respiratory infections (LRIS), including acute lower respiratory tract infections, pneumonia, atypical pneumonia, bronchitis, bronchiolitis, and severe acute respiratory syndrome (SARS), continue to threaten the health of children worldwide and especially in developing countries, where poor nutrition prevails and access to health care is scarce [11].

Therefore, the purpose of this study was to identify the incidence of hyponatraemia in children with CAP, to find predictive tools in order to classify the severity and outcome of CAP and also to explore possible differences of clinical importance between the two sexes.

\section{Material and methods}

The files of children hospitalized due to pneumonia in the $2^{\text {nd }}$ Department of Paediatrics, Medical School, Aristotle University of Thessaloniki, were retroprospectively reviewed. Participants in the study were chosen randomly from those that were hospitalized from January 2008 to May 2009. Information on sociodemographic variables including child's age and gender, and also clinical features of pneumonia, such as the presence and duration of fever, cough, nasal congestion, thoracic or abdominal pain and the duration of hospitalization were also recorded. Moreover, laboratory examinations, including nonspecific markers of inflammation, such as white blood cells (WBC), erythrocyte sedimentation rate (ESR), $\mathrm{CRP}$, and also biochemical examinations (including electrolytes, liver and kidney function) were performed in order to find possible predictors of pneumonia's severity and outcome. In order to be more specific sodium $(\mathrm{Na})$, potassium $(\mathrm{K})$, urea $(\mathrm{Ur})$, creatinine $(\mathrm{Cr})$, glucose (Glu), serum glutamic oxaloacetic transaminase (SGOT) and serum glutamate pyruvate transaminase (SGPT) were measured. Moreover, laboratory examinations were done at the admission of the child to the hospital, irrespective of the time of admission.

Since there was no control group to correlate our findings, the study group was subdivided into two groups based on patients' gender.

Hyponatraemia was defined as a sodium level of $<135 \mathrm{mmol} / \mathrm{l}$ in serum $[12,13]$. The severity of HN was determined by the reports of Ellison and Berl [8]. Serum concentration of 131-135 mmol/l means mild $\mathrm{HN}, 126-130 \mathrm{mmol} / \mathrm{l}$ means moderate $\mathrm{HN}$, and $\leq 125 \mathrm{mmol} / \mathrm{l}$ means severe HN [2]. Hypernatraemia was defined as a serum sodium concentration > $145 \mathrm{mmol} / \mathrm{l}$ [2].

\section{Statistical analysis}

The statistical analysis was performed using SPSS 12.00 for Windows (SPSS Inc, Chicago IL). Frequencies and descriptive statistics were used primarily in order to describe the sample's overall attitudes. The distribution of the population in various groups was described by mean value \pm standard error (SE). $\chi^{2}$ test and Fisher's exact test were used for qualitative variables in order to calculate $p$ values, while regression analysis was used for quantitative variables.

Student's t-test or one-way analysis of variance (ANOVA) was used for normally distributed variables, while the Mann-Whitney test was used for variables not normally distributed. Values of $p<0.05$ were considered as significant.

\section{Results}

The study population consisted of 54 children, 0.20-12.0 years old (mean \pm SE: $4.67 \pm 0.39$ years). There were 32 males (59.25\%) and 22 females (40.75\%). The duration of their hospitalization was 2.0-15.0 days (mean \pm SE: $5.42 \pm 0.42$ days). The majority of them presented cough (44/54, 81.50\%), and fever (53/54, 98.15\%). Admission body temperature was variable, ranging between $36.2^{\circ} \mathrm{C}$ and $41.0^{\circ} \mathrm{C}$ (mean $\pm \mathrm{SE}: 37.96 \pm 0.17^{\circ} \mathrm{C}$ ). Fever was present for 0 - 15 days ( $4.24 \pm 0.43$ days) before entrance to the hospital, and lasted for 0.0-11.0 days (2.75 \pm 0.27 days) after admission day. Moreover, cough was present 0.0-10.0 days before hospitalization (mean \pm SE: $4.10 \pm 0.43$ days) in children with pneumonia. Nasal congestion and abdominal pain were described in about one third of them $(16 / 54,29.60 \%$ and $17 / 54,31.50 \%$ respectively). Thoracic pain and vomiting were recorded only in $9 / 54$ (16.70\%) and 5/54 (9.25\%) of them respectively. One third of the children with pneumonia had previously received antibiotics (18/54, 33.33\%). Seven children developed pleural effusion. The outcome of all patients was 
favourable. Laboratory values of both sexes are presented in Table I.

There were no statistically significant differences between age of hospitalized children with pneumonia and their sex $(p=0.25)$ or the presence of abdominal pain $(p=0.27)$. However, older children (mean age \pm SE: $6.93 \pm 1.11$ years) more often $(p=0.01)$ present thoracic pain compared with younger ones (mean age \pm SE: $4.22 \pm 0.38$ years). Moreover, there was no statistically significant difference between the duration of hospitalization and the presence of thoracic $(r=-0.96, p=0.33)$ or abdominal pain $(z=-1.04, p=0.29)$.

A correlation was found between the duration of hospitalization: a) and the duration of fever after admission ( $p=0.004)$, and $b$ ) the value of CRP at admission $(p=0.00)$. There was also a correlation between the value of serum sodium at admission and erythrocyte sedimentation rate $(p=0.02)$.

Furthermore, CRP value and leukocyte count were correlated with admission value of sodium in serum ( $p=0.00$ and $p=0.006$ respectively). Finally, there was a negative association between the degree of hyponatraemia and the length of hospitalization $(z=-3.39, p=0.001)$.
Correlations were also performed between the two sexes concerning their age, days of hospitalization, body temperature at admission $\left({ }^{\circ} \mathrm{C}\right)$, duration of fever before and after admission, duration of cough, respiratory and heart rate at admission, $\mathrm{SatO}_{2}(\%)$ and the value of serum sodium at admission. No statistically significant differences between the two groups were found (Table II).

\section{Discussion}

Hyponatraemia could result from a sodium deficit, or surplus of water. Primary illness, impaired water excretion, "inappropriate" release of vasopressin, use of hypotonic fluids, redistribution of sodium and water, sickle cell syndrome, and several drugs may contribute to hyponatraemia $[3,14]$.

Hyponatraemia is a frequent finding in children with pneumonia. Usually, it comprises part of the syndrome of inappropriate SIADH $[10,15,16]$. Secretion of anti-diuretic hormone typically results in water retention with minimal weight gain, usually with no oedema formation, and normal blood pressure [10]. According to studies, SIADH occurs in

Table I. Laboratory values of children with pneumonia

\begin{tabular}{|c|c|c|}
\hline \multirow[t]{2}{*}{ Laboratory values } & Boys & Girls \\
\hline & Mean \pm SE (range) & Mean \pm SE (range) \\
\hline \multirow{2}{*}{$\begin{array}{l}\text { WBC } \\
{[K / \mu l]}\end{array}$} & $16421.87 \pm 1530.17(5130.0-35000.0)$ & $17734.09 \pm 2188.46(6460.0-41$ 100.0) \\
\hline & \multicolumn{2}{|c|}{$p=0.97, z=-0.04$} \\
\hline \multirow{2}{*}{$\begin{array}{l}\text { ESR } \\
{[\mathrm{mm}]}\end{array}$} & $11.74 \pm 0.22(8.80-13.80)$ & $11.83 \pm 0.33(9.70-17.70)$ \\
\hline & \multicolumn{2}{|c|}{$p=0.17, z=-1.36$} \\
\hline \multirow{2}{*}{$\begin{array}{l}\text { CRP } \\
{[\mathrm{mg} / \mathrm{dl}]}\end{array}$} & $12.20 \pm 2.42(0.32-41.83)$ & $14.76 \pm 3.11(0.08-51.20)$ \\
\hline & \multicolumn{2}{|c|}{$p=0.51, z=-0.70$} \\
\hline \multirow{2}{*}{$\begin{array}{l}\text { PCT } \\
{[\mathrm{ng} / \mathrm{ml}]}\end{array}$} & $4.13 \pm 1.63(0.20-20.40)$ & $3.64 \pm 1.15(0.10-10.70)$ \\
\hline & \multicolumn{2}{|c|}{$p=0.70, z=-0.42$} \\
\hline \multirow{2}{*}{$\begin{array}{l}\mathrm{Na} \\
{[\mathrm{mmol} / \mathrm{l}]}\end{array}$} & $136.09 \pm 0.54(127.0-142.0)$ & $136.54 \pm 0.61(128.0-141.0)$ \\
\hline & \multicolumn{2}{|c|}{$p=0.46, z=-0.74$} \\
\hline \multirow{2}{*}{$\begin{array}{l}\mathrm{K} \\
{[\mathrm{mmol} / \mathrm{l}]}\end{array}$} & $4.43 \pm 0.08(3.60-5.80)$ & $4.47 \pm 0.10(3.90-5.80)$ \\
\hline & \multicolumn{2}{|c|}{$p=0.98, z=-0.02$} \\
\hline \multirow{2}{*}{$\begin{array}{l}\text { Ur } \\
{[\mathrm{mg} / \mathrm{dl}]}\end{array}$} & $24.63 \pm 1.67(0.44-42.0)$ & $23.54 \pm 1.82(11.0-45.0)$ \\
\hline & \multicolumn{2}{|c|}{$p=0.57, z=-0.56$} \\
\hline \multirow{2}{*}{$\begin{array}{l}\mathrm{Cr} \\
{[\mathrm{mg} / \mathrm{dl}]}\end{array}$} & $0.48 \pm 0.05(0.11-1.90)$ & $0.43 \pm 0.03(0.17-0.70)$ \\
\hline & \multicolumn{2}{|c|}{$p=0.52, z=-0.64$} \\
\hline \multirow{2}{*}{$\begin{array}{l}\text { Glu } \\
{[\mathrm{mg} / \mathrm{dl}]}\end{array}$} & $102.13 \pm 4.55(68.0-165.0)$ & $89.0 \pm 3.40(55.0-125.0)$ \\
\hline & \multicolumn{2}{|c|}{$p=0.06, z=-1.87$} \\
\hline \multirow{2}{*}{$\begin{array}{l}\text { SGOT } \\
{[U / I]}\end{array}$} & $27.96 \pm 1.84(4.0-49.0)$ & $34.0 \pm 3.99(17.0-84.0)$ \\
\hline & \multicolumn{2}{|c|}{$p=0.54, z=-0.61$} \\
\hline \multirow{2}{*}{$\begin{array}{l}\text { SGPT } \\
{[U / I]}\end{array}$} & $14.0 \pm 0.91(6.0-23.0)$ & $18.36 \pm 3.38(4.0-62.0)$ \\
\hline & \multicolumn{2}{|c|}{$p=0.77, z=-0.29$} \\
\hline
\end{tabular}


Table II. Correlations between sexes in cases of children with pneumonia

\begin{tabular}{|c|c|c|c|}
\hline \multirow[t]{2}{*}{ Characteristics of pneumonia } & \multicolumn{2}{|c|}{ SEX } & \multirow[t]{2}{*}{ Value of $p$} \\
\hline & Boys, $n(\%)$ & Girls, $n(\%)$ & \\
\hline Patients & $32(59.25)$ & $22(40.75)$ & \\
\hline $\begin{array}{l}\text { Age [years] } \\
\text { (mean } \pm \mathrm{SE}) \\
\text { (range) }\end{array}$ & $\begin{array}{l}4.97 \pm 0.52 \\
(0.45-12.0)\end{array}$ & $\begin{array}{c}4.24 \pm 0.58 \\
(0.2-11.0)\end{array}$ & $p=0.255, z=-1.139$ \\
\hline $\begin{array}{l}\text { Days of hospitalization } \\
\text { (mean } \pm \mathrm{SE}) \\
\text { (range) }\end{array}$ & $\begin{array}{c}5.78 \pm 3.309 \\
(2.0-15.0)\end{array}$ & $\begin{array}{l}4.90 \pm 2.71 \\
(2.0-14.0)\end{array}$ & $p=0.317, \mathrm{~d} f=51$ \\
\hline $\begin{array}{l}\text { Temperature at admission }\left[{ }^{\circ} \mathrm{C}\right] \\
(\text { mean } \pm \mathrm{SE}) \\
\text { (range) }\end{array}$ & $\begin{array}{c}38.13 \pm 1.23 \\
(36.20-41.0)\end{array}$ & $\begin{array}{c}37.63 \pm 1.03 \\
(36.20-39.50)\end{array}$ & $p=0.157, z=-1.414$ \\
\hline $\begin{array}{l}\text { Duration of fever before admission [days] } \\
(\text { mean } \pm \mathrm{SE}) \\
\text { (range) }\end{array}$ & $\begin{array}{l}3.82 \pm 2.82 \\
(0.0-10.0)\end{array}$ & $\begin{array}{c}4.92 \pm 3.66 \\
(1.0-15.0)\end{array}$ & $p=0.26, z=-1.123$ \\
\hline $\begin{array}{l}\text { Duration of fever after admission [days] } \\
\text { (mean } \pm \mathrm{SE}) \\
\text { (range) }\end{array}$ & $\begin{array}{l}3.79 \pm 3.14 \\
(0.0-10.0)\end{array}$ & $\begin{array}{l}4.57 \pm 3.32 \\
(0.0-10.0)\end{array}$ & $p=0.807, \mathrm{~d} f=51$ \\
\hline $\begin{array}{l}\text { Duration of cough [days] } \\
\text { (mean } \pm \mathrm{SE}) \\
\text { (range) }\end{array}$ & $\begin{array}{l}3.79 \pm 3.14 \\
(0.0-10.0)\end{array}$ & $\begin{array}{l}4.57 \pm 3.32 \\
(0.0-10.0)\end{array}$ & $p=0.34, z=-0.95$ \\
\hline $\begin{array}{l}\text { Respiratory rate at admission [breaths/min] } \\
(\text { mean } \pm \mathrm{SE}) \\
\text { (range) }\end{array}$ & $\begin{array}{c}37.13 \pm 14.17 \\
(16.0-75.0)\end{array}$ & $\begin{array}{c}36.92 \pm 11.78 \\
(22.0-60.0)\end{array}$ & $p=0.98, z=-0.016$ \\
\hline $\begin{array}{l}\text { Heart rate at admission [pulses } / \mathrm{min}] \\
(\text { mean } \pm \mathrm{SE}) \\
(\text { range) }\end{array}$ & $\begin{array}{c}128.52 \pm 25.66 \\
(88.0-180.0)\end{array}$ & $\begin{array}{c}132.33 \pm 20.96 \\
(100.0-178.0)\end{array}$ & $p=0.38, z=-0.87$ \\
\hline $\begin{array}{l}\mathrm{SatO}_{2}[\%] \text { at admission } \\
\text { (mean } \pm \mathrm{SE}) \\
\text { (range) }\end{array}$ & $\begin{array}{c}95.76 \pm 2.67 \\
(90.0-100.0)\end{array}$ & $\begin{array}{c}96.0 \pm 1.82 \\
(93.0-99.0)\end{array}$ & $p=0.96, z=-0.047$ \\
\hline $\begin{array}{l}\text { Value of serum sodium at admission }[\mathrm{mmol} / \mathrm{l}] \\
(\text { mean } \pm \mathrm{SE}) \\
\text { (range) }\end{array}$ & $\begin{array}{c}136.0 \pm 3.10 \\
(127.0-142.0)\end{array}$ & $\begin{array}{l}136.47 \pm 2.96 \\
(128.0-141.0)\end{array}$ & $p=0.458, z=-0.74$ \\
\hline
\end{tabular}

about one third of children hospitalized for pneumonia, and was associated with a more severe disease and a poorer outcome [10].

Few studies exist concerning the correlation of HN and pneumonia in children. It was first described by Stormont and Waterhouse in 1962 [17]. Since then and during the past 35 years, only case reports and a few relevant studies on the association between $\mathrm{HN}$ and pneumonia have been published, of which only three concern children [10, 18, 19]. Community-acquired (CAP) and nosocomial pneumonias contribute substantially to morbidity and hospital resource utilization [20, 21]. Hyponatraemia, occurring in more than $1 / 4$ of patients with CAP, is associated with greater disease severity and worsened outcomes [20].

In the present study, only $33.33 \%$ of children had mild hyponatraemia and 1 child $(1.90 \%)$ moderate $\mathrm{HN}$. Moreover, children with more severe HN had a longer duration of hospitalization $(z=-3.40$, $p=0.001$, findings that are consistent with previously published data [20].

Hyponatraemia is usually mild in children with CAP [9]. It seems that high atrial natriuretic peptide levels (ANP) may play a role [15]. Atrial natriuretic peptide is a member of the family of natriuretic peptides, and regulates a variety of physiological parameters, such as diuresis and natriuresis, and reduces systemic blood pressure. It is synthesized and secreted from cardiac atria [15]. Increased levels of ANP were found in diseases affecting the lungs. Over-secretion of ANP is correlated with hypoxia, which leads to pulmonary vasoconstriction, pulmonary hypertension, and right-heart overload $[22,23]$.

Severe HN is rare in children with CAP, as in our study where only one child presented a moderate degree of HN (1\%). This can be explained by the observations of Haviv et al. [15]. According to them, the ANP through its natriuretic, diuretic and 
vasodilatatory effects may contribute in maintaining water and electrolyte balance in children with pneumonia and SIADH. Gerigk et al. [24] found that $\mathrm{ADH}$ may cause HN that may originate by a nonosmotic, cardiovascular mechanism in acutely ill children, including children with pneumonia.

Based on studies, symptoms and signs indicative of severe pneumonia were two to three times more frequent and the mean duration of tachypnoea, chest wall retraction and hospital stay about 50\% longer in children with HN [10]. In the present study, children with increased heart rhythm and tachypnoea at admission presented lower values of sodium $(z=-2.66, p=0.007$ and $z=-1.70, p=0.089$ respectively).

The analysis of non-specific inflammatory markers (CRP, WBC, ESR) has shown a significant association between the presence of $\mathrm{HN}$ and elevated levels of WBC [9]. A significant association also exists between $\mathrm{HN}$ and fever, increased WBC count and CRP levels and the need for hospital treatment. All these parameters reflect the severity of pneumonia, but without taking into consideration the radiological pattern of pneumonia or the length of hospital stay and the aetiological agent $[9,25]$.

In our study there was also a correlation between leukocyte count $(z=-2.010, p=0.04)$, sedimentation rate $(z=-2.42, p=0.01), \operatorname{CRP}(z=-3.76, p=0.00)$, and levels of sodium at admission to hospital. It should be pointed out that no statistical associations were analysed between PCT and other factors/markers, since only in a few children with pneumonia (fewer than ten) was PCT measured at admission to the hospital.

Hyponatraemia, the most common frequent electrolyte derangement identified among hospitalized patients, is associated with worsened outcomes in patients with pneumonia, heart failure and other disorders [26]. Hyponatraemia is common among hospitalized patients with pneumonia and is associated with worsened clinical and economic outcomes and indicates a poor prognosis [20, 25]. A recent single-centre cohort study found the incidence of $\mathrm{HN}$ at hospital admission among CAP patients to be $28 \%$ [26]. It is important to emphasize that the presence of HN was associated with not only prolongation of hospitalization (HLOS), but also with an increase in hospital mortality [20]. In our study, children with $\mathrm{HN}$ at admission had longer hospitalization times and a prolonged duration of fever, although their final outcome was favourable, including cases that developed pleural effusion.

Although no differences were found in our study between the two sexes concerning the characteristics of pneumonia or the range of serum sodium at admission (Table II), it is important to emphasize the originality of our study since no data exist as far as we could find by checking electronic resources on this topic.

In conclusion, our findings further confirm the fact that mild $\mathrm{HN}$ is common among hospitalized patients with pneumonia and influences hospital length of stay. Thus, it contributes to increased morbidity rates and probably adds to the costs of care. However, a limitation of the study was the relatively small size of our study group, since only one child with pneumonia had moderate HN. Thus, studies in larger population groups are needed in order to evaluate whether the degree of HN could impact the outcome of hospitalized children with CAP and whether sex is a risk factor for the development of $\mathrm{HN}$ in cases of children with pneumonia.

The evaluation of the severity of CAP should include clinical markers, such as heart rate and respiratory rate, and also biochemical indexes, such as leukocyte count, ESR, CRP and serum levels of sodium.

\section{References}

1. Anderson RJ, Chung Hsiao Min, Kluge R, Schrier RW. Hyponatremia: a prospective analysis of its epidemiology and the pathogenic role of vasopressin. Ann Intern Med 1985; 102: 164-8.

2. Moritz ML, Ayus JC. Disorders of water metabolism in children: hyponatremia and hypernatremia. Pediatr Rev 2002; 23: 371-80.

3. Laczi F. Etiology, diagnostics and therapy of hyponatremias. Orv Hetil 2008; 149: 1347-54.

4. Lussky HO, Friedstein $\mathrm{H}$. Water retention in pneumonia. Am J Dis Child 1920; 19: 337-43.

5. Darrow DC, Hartmann AF. Chemical changes occurring in the body as a result of certain diseases. IV. Primary pneumonia in children. Am J Dis Child 1929; 37: 323-34.

6. Rivers RP, Forsling ML, Olver RP. Inappropriate secretion of anti-diuretic hormone in infants with respiratory infections. Arch Dis Child 1981; 56: 358-63.

7. Kaplan SL, Feigin RD. The syndrome of inappropriate secretion of antidiuretic hormone in children with bacterial meningitis. J Pediatr 1978; 92: 758-61.

8. Ellison DH, Berl T. Clinical Practice. The syndrome of inappropriate antidiuresis. N Engl J Med 2007; 356: 2064-72.

9. Don M, Valerio G, Korppi M, Canciani M. Hyponatremia in pediatric community-acquired pneumonia. Pediatr Nephrol 2008; 23: 2247-53.

10. Dhawan A, Narang A, Singhi S. Hyponatraemia and the inappropriate ADH syndrome in pneumonia. Ann Trop Paediatr 1992; 12: 455-62.

11. Eboriadou M, Haidopoulou K, Xanthou P, Papa A. Coronaviruses OC43 and 229E lower respiratory tract coinfections: a clinical report of two cases. Arch Med Sci 2008; 4: 88-90.

12. Oh MS. Pathogenesis and diagnosis of hyponatremia. Nephron 2002; 92 (Suppl 1): 2-8.

13. Smith DM, McKenna K, Thomson CJ. Hyponatraemia. Clin Endocrinol (Oxford) 2000; 52: 667-78.

14. Ellison DH, Berl T. The syndrome of inappropriate antidiuresis. N Engl J Med 2007; 356: 2064-72. 
15. Haviv M, Haver E, Lichtstein D, Hurvitz H, Klar A. Atrial natriuretic peptide in children with pneumonia. Pediatr Pulmonol 2005; 40: 306-9.

16. Haycock GB. The syndrome of inappropriate secretion of antidiuretic hormone. Pediatr Nephrol 1995; 9: 375-81.

17. Stormont JM, Waterhouse C. Severe hyponatraemia associated with pneumonia. Metabolism 1962; 11: 1181-6.

18. Shann F, Germer S. Hyponatraemia associated with pneumonia or bacterial meningitis. Arch Dis Child 1985; 60: 963-6.

19. Nair V, Niederman MS, Masani F, Fishbane S. Hyponatremia in community-acquired pneumonia. Am J Nephrol 2007; 27: 184-190.

20. Zilberberg MD, Exuzides A, Spalding J, et al. Hyponatremia and hospital outcomes among patients with pneumonia: a retrospective cohort study. BMC Pulmonary Medicine 2008; 8: 16.

21. Jabłoński S, Modrzewski W, Rysz J, Machała W, Jabłonowski Z, Kordiak J. Pulmonary abscesses - aetiology and treatment. Ten-year experience of the Department of General and Thoracic Surgery in Lodz, Poland. Arch Med Sci 2006; 2: 47-54

22. Yap LB, Mukerjee D, Timms PM, Ashrafian H, Coghlan JG. Natriuretic peptides, respiratory disease, and the right heart. Chest 2004; 126: 1330-6.

23. Wilkins MR, Redondo J, Brown LA. The natriuretic-peptide family. Lancet 1997; 349: 1307-10.

24. Gerigk M, Gnehm HE, Rascher W. Arginine vasopressin and renin in acutely ill children: implication for fluid therapy. Acta Paediatr 1996; 85: 550-3.

25. Nair V, Niederman MS, Masani N, Fishbane S. Hyponatremia in community-acquired pneumonia. Am J Nephrol 2007; 27: 184-90.

26. Zilberberg MD, Exuzides A, Spalding J, et al. Epidemiology, clinical and economic outcomes of admission hyponatremia among hospitalized patients. Curr Med Res Opin 2008; 24: 1601-8. 